\title{
Common Blepharitis Related to Phthiriasis Palpebrarum: Argon Laser Phototherapy
}

\author{
Pitriazis Palpebrarum ile İlişkili Yaygın Blefarit: Argon Lazer Fototerapi
}

\author{
Cem Sunduํ, Erdem Dinç ${ }^{1}$, Umut Can Kurtuluş², Özlem Yıldırım \\ 'Department of Ophthalmology, Mersin University, Mersin, Turkey \\ ${ }^{2}$ Clinic of Ophthalmology, Aşkım Tüfekçi State Hospital, Adana, Turkey
}

\begin{abstract}
A 42-year-old woman was admitted to Mersin University, Department of Ophthalmology Clinic with itching and burning sensation of the right eye for 3 weeks. In her slit-lamp examination, nits and lice, attached to the upper and lower eyelashes of her right eye, were observed. Lice and nits were destroyed by argon laser phototherapy and were removed with the help of a fine forceps thereafter. Argon laser phototherapy is a quick, effective, and safe treatment modality for phthiriasis palpebrarum. (Turkiye Parazitol Derg 2015; 39: 252-4)
\end{abstract}

Keywords: Phthiriasis palpebrarum, Pthirus pubis, blepharitis, laser photocoagulation treatment, argon laser

Received: 22.09.2014

Accepted: 19.01.2015

\section{ÖZ}

Kırk iki yaşındaki bayan hasta sağ gözünde 3 haftadır devam eden kaşıntı ve yanma şikayeti ile kliniğimize başvurdu. Biomikroskopik muayenede sağ gözde alt ve üst kapakta kirpiklere sıkıca yapışık olan sirkelerin ve bitlerin olduğu izlendi. Bitler ve sirkeler argon lazer ile öldürüldü ve forseps yardımıyla uzaklaştııılı. Argon lazer fototerapi phthiriasis palpebrarum tedavisinde hızlı, etkin ve güvenilir tedavi yöntemlerinden birisidir. (Turkiye Parazitol Derg 2015; 39: 252-4)

Anahtar Kelimeler: Pitriazis palpebrarum, Pthiruspubis, blefarit, argon lazer

Geliş Tarihi: 22.09.2014

\section{INTRODUCTION}

Phthiriasis palpebrarum is a rare eyelid infestation caused by the pubic louse, Phthirus pubis (1), and it can be seen in people with low hygiene. The louse is usually transmitted between adults by close physical (sexual) contact. The infestation of eyelashes with P. pubis usually occurs through hands after contact of the infested genital area or by sexual contact. In infants and children with phthiriasis palpebrarum, physicians must be aware of possible child abuse, especially if the mother is not infested (2). Furthermore, isolated palpebral involvement has been reported by Turgut et al. (3).

Pediculus species typically infest the hair, but infestation of the cilia and eyelids is rare. Phthiriasis palpebrarum can be the cause of blepharitis, and sometimes it can be misdiagnosed as isolated common blepharitis (4). Argon laser phototherapy is an alternative, quick, and effective method for treating phthiriasis palpebrarum (5). We report a case of blepharitis related to phthiriasis palpebrarum and its treatment with an argon laser.

Address for Correspondence / Yazışma Adresi: Dr. Cem Sundu. E.mail: cemsundu@hotmail.com DOI: $10.5152 /$ tpd.2015.3861

(C) Copyright 2015 Turkish Society for Parasitology - Available online at www.tparazitolderg.org

(C) Telif hakkı 2015 Türkiye Parazitoloji Derneği - Makale metnine www.tparazitolderg.org web sayfasından ulaşılabilir. 


\section{CASE REPORT}

A 42-year-old woman was admitted to the clinic with itching and burning sensation of the upper and lower eyelashes lids of her right eye for 3 weeks. External examination of the right periorbital region exfoliative lesions and color changes in the eyelids was observed. In ophthalmologic examination best corrected visual acuity was 20/20 in both eyes. Slit-lamp examination revealed nits and lice anchored to the upper and lower eyelashes of her right eye (Figure 1), while the eyelashes on her left eye were normal. The anterior segment and fundus examination was normal in both eyes. She had stayed in a hospital for a week as a companion. There were no similar complaints in her family. She did not complain about any discomfort in the genital area, and the examination of that area did not reveal any abnormalities, and no lice could be found. She was diagnosed with phthiriasis palpebrarum based on the clinical findings. Under topical anesthesia (proparacaine 0.5\%), a corneal conformer was applied to the ocular surface to protect the eye from laser light. The lice and eggs were destroyed by argon laser phototherapy (200 micron size, $0.1 \mathrm{~s}$ time, and $700 \mathrm{~mW}$ power for the lice $/ 300 \mathrm{~mW}$ power for the eggs) and were removed with the help of a fine forceps after the laser treatment. Topical tobramycin ointment was applied four times daily over the lid margins by the patient. Detailed informed consent was taken from the patient. One week later, one louse was observed on the upper lid margin, and the same protocol was used to destroy it. Two weeks later, the eyelashes were normal (Figure 2), and no new infestation could be seen for two weeks.

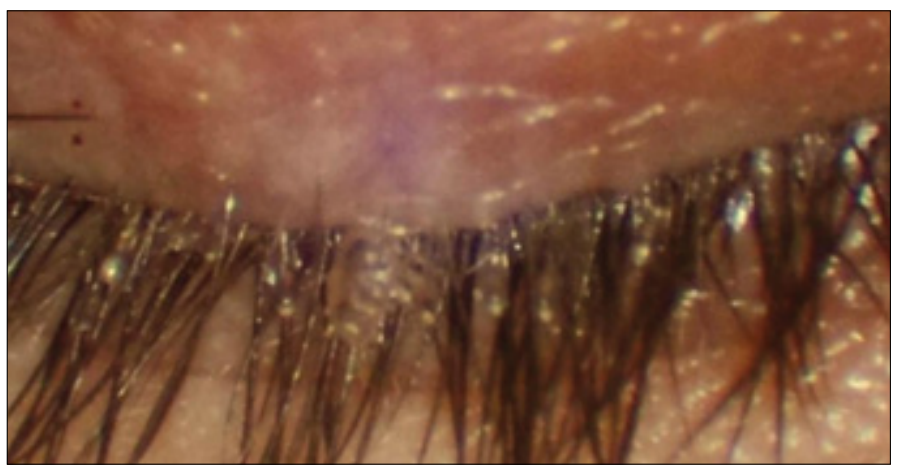

Figure 1. Slit-lamp examination: lice and nits anchored to the eyelashes

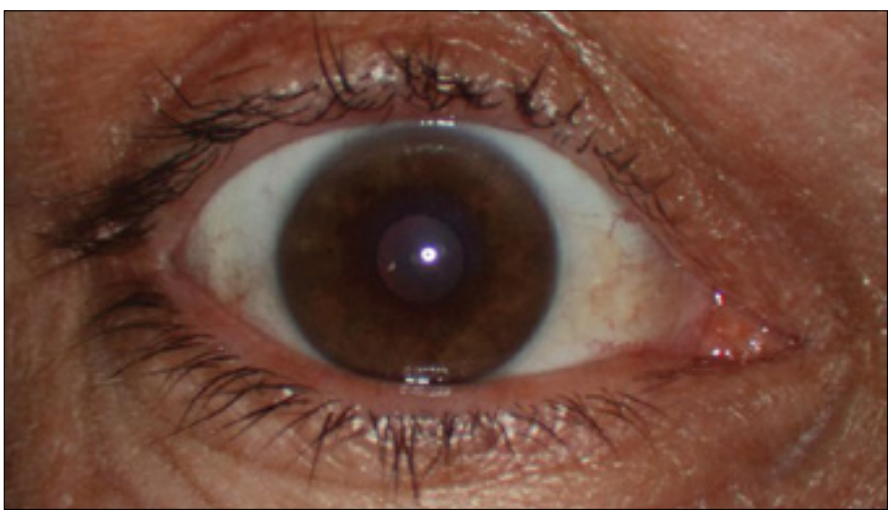

Figure 2. The condition of the eyelids three weeks after treatment

\section{DISCUSSION}

Phthiriasis palpebrarum is a rare condition in developed countries. Infestation with Phthirus pubis is usually associated with poor hygiene in an overcrowded environment. Pubic lice infestations are seen in the adult population approximately $2 \%$ worldwide (6). In USA, it is about $2-10 \%$, especially in the sexually active age groups (7). Furthermore, it has become an important public health problem.

In heavy infestations, pubic lice are also found in the axillary hair, chest, eyebrows, and eyelashes. The infestation of Pthirus pubis on the eyelashes could be caused by hand contact from the genital area to the eye. Ocular signs and symptoms include itching, irritation, erythematous lesions, secondary blepharitis, follicular conjunctivitis, and marginal keratitis (8). It is an uncommon cause of blepharitis and conjunctivitis and may be easily overlooked (9). Careful examination of the patient's lid margins and eyelashes help to lead to a proper diagnosis.

Previously reported treatments for phthiriasis palpebrarum include trimming or plucking the eyelashes, mechanical removal of the lice with a fine forceps, cryotherapy, argon laser photocoagulation, traumatic amputation, fluorescein eye drops (20\%), physostigmine $(0.25 \%)$, lindane (1\%), petroleum jelly, yellow mercuric oxide (1\%), malathion drops (1\%), malathion shampoo (1\%), permethrin shampoo (1\%), as well as oral ivermectin and pilocarpine drops (4\%) $(4,5$, $8,9)$. Argon lasers are used to treat lesions on the retina or to eliminate diseased parts of the retina that may affect the healthy retina, such as diabetic retinopathy or retinal vein occlusion.

\section{CONCLUSION}

The most popular treatment modality is the direct removal of the parasites with a forceps (10). However, this method can be dangerous and painful because nits and lice are strongly anchored to the eyelashes. Therefore, parasites can be destroyed by argon laser phototherapy before mechanical removal. In literature, we found one case where the disease was treated with an argon laser (5). Compared with this study, we applied more power to the area because treatment with lower power did not give satisfactory results. The parasites were easily removed after laser phototherapy. The eye should be protected from laser light during the treatment.

Informed Consent: Written informed consent was obtained from the patient.

Peer-review: Externally peer-reviewed.

Author Contributions: Consept - C.S., E.D.; Design - C.S, U.C.K.; Supervision - Ö.Y.; Funding - Ö.Y.; Materials - C.S., E.D.; Data Collection and/or Processing - C.S., E.D.; Analysis and/or Interpretation - C.S. E.D.; Literature Review - C.S., E.D.; Writer - C.S.; Critical Review - E.D., Ö.Y.

Conflict of Interest: No conflict of interest was declared by the authors.

Financial Disclosure: The authors declared that this study has received no financial support.

Hasta Onamı: Yazılı hasta onamı hastadan alınmıştır.

Hakem Değerlendirmesi: Dış Bağımsız. 
Yazar Katkıları: Fikir - C.S., E.D.; Tasarım - C.S., U.C.K.; Denetleme - Ö.Y.; Kaynaklar - Ö.Y.; Malzemeler - C.S., E.D.; Veri Toplanması ve/veya işlemesi - C.S., E.D.; Analizve/veyaYorum - C.S., E.D.; Literatür taraması - C.S., E.D.; Yazıyı Yazan - C.S.; Eleştirel İnceleme - E.D., Ö.Y.

Çıkar Çatışması: Yazarlar çıkar çatışması bildirmemişlerdir.

Finansal Destek: Yazarlar bu çalışma için finansal destek almadıklarını beyan etmişlerdir.

\section{REFERENCES}

1. Gökpınar S, Aydenizöz M. Protozoons and arthropods found in eyes. Turkiye Parazitol Derg 2010; 34: 137-44.

2. Ryan MF. Phthiriasis palpebrarum infection: aconcern for child abuse. J Emerg Med 2014; 46: e159-62. [CrossRef]

3. Turgut $B$, Kurt J, Çatak $O$, Demir T. Phthiriasis palpebrarum mimicking lid eczema and blepharitis. J Opthalmol 2009; 2009: 803951.

4. Jiang J, Shen T, Hong CY. A peculiar case of eye pruritus: phthiriasispalpebrarum initially misdiagnosed as common blepharitis. Int $\mathrm{J}$ Ophthalmol 2011; 4: 676-7.
5. Awan KJ. Argon laser phototherapy of phthiriasispalpebrarum Ophthalmic Surg 1986; 17: 813-4.

6. Anderson AL, Chaney E. Pubic lice (Pthirus pubis): history, biology and treatment vs. knowledge and beliefs of US college students. Int J Environ Res Public Health 2009; 6: 592-600. [CrossRef]

7. Mimouni D, Ankol OE, Gdalevich M, Grotto I, Davidovitch N, Zangvil E. Seasonality trends of Pediculosis capitis and Phthirus pubis in a young adult population: Follow-up of 20 years. J Eur Acad Dermatol Venereol 2002; 16: 257-9. [CrossRef]

8. Couch JM, Green WR, Hirst LW, de la Cruz ZC. Diagnosing and treating Phthirus pubis palpebrarum. Surv Ophthalmol 1982; 26: 219-25. [CrossRef]

9. Panos GD, Petropoulos IK, Dardabounis D, Gatzioufas Z. Phthiriasis palpebrarum. BMJ Case Rep 2013; 2013: pii: bcr2013009272.

10. Keklikci U, Cakmak A, Akpolat N, Unlu K, Ozkul S. Phthiriasis palpebrarum in an infant. J Pediatr Ophthalmol Strabismus 2009; 46: 173-4. [CrossRef] 